\title{
Noise annoyance through railway traffic - a case study
}

\author{
Paulo Henrique Trombetta Zannin ${ }^{*}$ and Fernando Bunn
}

\begin{abstract}
This paper describes an assessment of noise caused by railway traffic in a large Latin American city. Measurements were taken of noise levels generated by trains passing through residential neighborhoods with and without blowing their horns. Noise maps were also calculated showing noise pollution generated by the train traffic. In addition - annoyance of the residents - affected by railway noise, was evaluated based on interviews. The measurements indicated that the noise levels generated by the passage of the train with its horn blowing are extremely high, clearly exceeding the daytime limits of equivalent sound pressure level - $L_{e q}=55 \mathrm{~dB}(\mathrm{~A})$ - established by the municipal laws No 10.625 of the city of Curitiba. The $L_{e q}=45 \mathrm{~dB}(\mathrm{~A})$ which is the limit for the night period also are exceeded during the passage of trains. The residents reported feeling affected by the noise generated by passing trains, which causes irritability, headaches, poor concentration and insomnia, and $88 \%$ of them claimed that nocturnal noise pollution is the most distressing. This study showed that the vast majority of residents surveyed, (69\%) believe that the noise of the train can devalue their property.
\end{abstract}

Keywords: Noise pollution, Railway noise, Noise measurements, Noise mapping, Environmental noise

\section{Introduction}

Noise pollution today is no longer restricted to industrial environments but affects small, medium and large cities all over the world. It is a daily reality both in developed countries such as the United States and the European nations and in emerging countries such as India, China and Brazil.

Many sectors of society are affected by noise, particular which is generated by traffic. Traffic noise road, air, and railway - causes discomfort and irritation, especially during activities that require attention and concentration [1-14].

Traffic noise is also a serious source of annoyance for people trying to rest and relax at home [15-18], particularly when it interferes with sleep, which is indispensable to human health, contributing to the degradation of quality-of-life [19-23].

Noise pollution in urban environments comes from numerous sources, e.g., sirens, loud music, neighbors, car and home alarms, religious temples, horns, motorcycles, trucks, passenger cars, buses, planes, trains, etc. [24-27].

\footnotetext{
* Correspondence: paulo.zannin@gmail.com

Laboratory of Environmental and Industrial Acoustics and Acoustic Comfort, Federal University of Paraná, Curitiba, Paraná, Brazil
}

Brazil's rail network currently covers approximately 30,000 kilometers, and accounts for over $20 \%$ of the country's freight transport [28]. Figure 1 compares the extent of the Brazilian rail network to that of other countries.

The Brazilian rail network is used primarily for transporting bulk commodities, such as soybeans, from the country's producing regions to its shipping ports for export. The port of Paranaguá, situated in the state of Paraná in southern Brazil, is one of the main export outlets for the country's agricultural production. In 2009, this shipping port handled 31.3 million tons of freight, of which approximately 8.6 million tons were transported by rail [30].

The railway line linking the producer regions in the interior of the state of Paraná to this shipping port was built in the late $19^{\text {th }}$ century. On its route to the shipping port the railway line passes through Curitiba, the capital of the state of Paraná. The 319-year-old city of Curitiba is one of the oldest in Brazil, with a population of approximately 1.8 million. The stretch of railway line that runs through the city covers about $20 \mathrm{~km}$. Figure 2 shows part of the route of the railway line through Curitiba.
C Biomed Central

(c) 2014 Zannin and Bunn; licensee BioMed Central Ltd. This is an open access article distributed under the terms of the Creative Commons Attribution License (http://creativecommons.org/licenses/by/2.0), which permits unrestricted use, distribution, and reproduction in any medium, provided the original work is properly cited. 


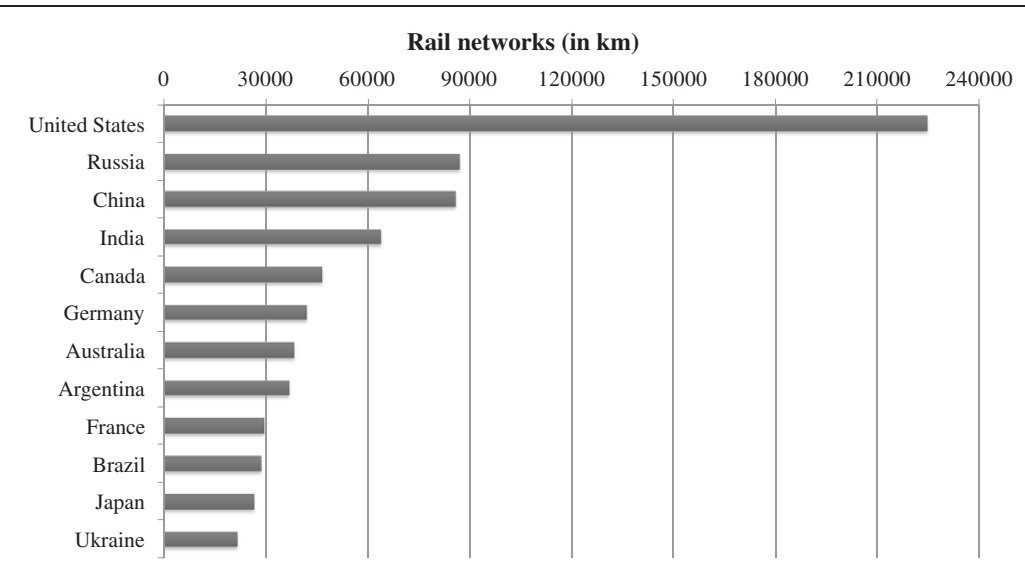

Figure 1 Extent of rail networks in several countries (Adapted from [29]).

On its route through the city, the railway line crosses urban thoroughfares and passes through residential neighborhoods. As a safety measure, trains blow their horn before they reach a railroad crossing (see Figure 3). However, there are no barriers that close automatically to prevent the passage of vehicles, and fatal accidents are not infrequent. Figure 4 shows a typical railroad crossing without barriers in Curitiba, unlike Germany, for instance, where they typically exist. Figure 5 shows safety signs drawing attention to railroad crossings. The trains pass through 40 crossings and blow their horn at least three times as they approach a crossing, thus blowing their horns at least 120 times as they pass through the city. Since an average of ten trains pass through the city each day, their horns are blown at least 1200 times per day.
The railway noise is a serious environmental problem, as reported in the lengthy study by Fields and Walker [22]. These authors evaluated the response to railway noise in residential areas in Great Britain, and reached the following conclusion: "Noise is rated as the most serious environmental nuisance caused by railways." The literature on environmental noise pollution contains several reports on railway noise in different countries, including the United Kingdom, France, Japan, Sweden, the Netherlands, the United States of America, Switzerland, and Germany [16,22,31-36]. In Brazil, however, studies about railway noise are as rare as to be practically nonexistent, with a very exceptions such as the works of Bertolli and de Paiva [37] and Roland and Zannin [38].

This paper describes an assessment of the annoyance caused by railway noise in a large Latin American

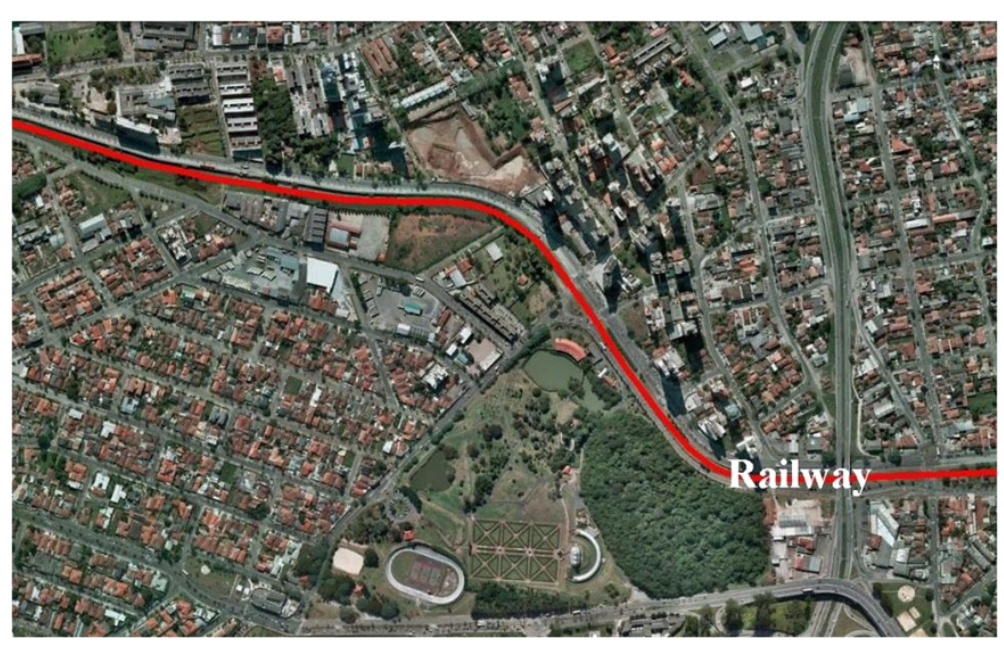

Figure 2 A portion of the route covered by the railway line in the city of Curitiba. Areas affected by train noise: Residential areas, Hospital and Public Park, Residential area under construction (five 12-story buildings). 


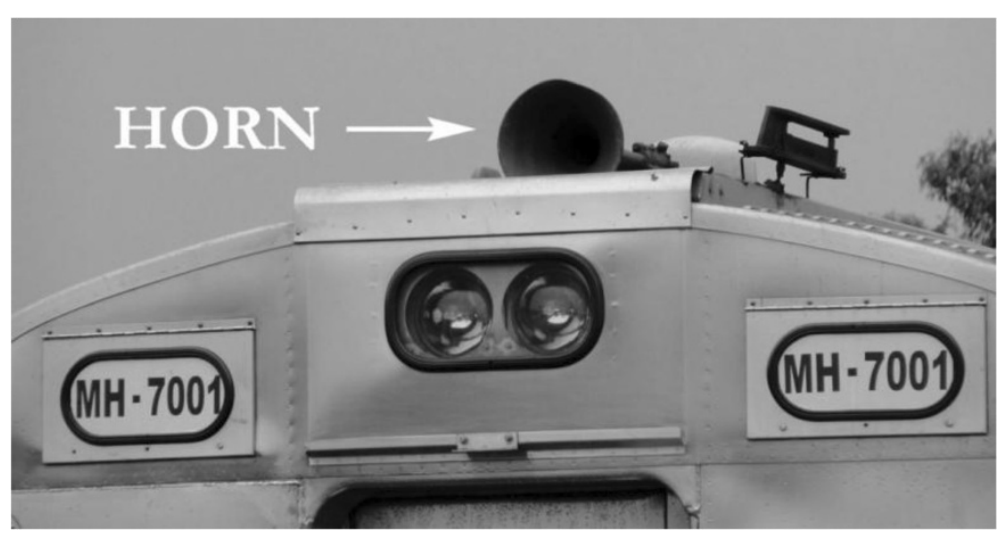

Figure 3 Photograph of a train horn mounted on the roof of the locomotive.

city, based on noise measurements, noise mapping, and interviews.

\section{Materials and methods}

The environmental impact generated by railway noise in the city of Curitiba was characterized based on several parameters: 1) noise level measurements at railroad crossings with the train horn blowing; 2) noise level measurements at railroad crossings without the train horn blowing; 3) noise maps showing the situation of noise pollution generated by train horn blowing; 4) noise maps without train horn blowing; 5) noise measurement at the receiver, i.e., inside the home of a resident in a neighborhood affected by railroad noise; and 6) interviews with the population of a district through which the railway runs.
The noise levels - equivalent sound pressure levels, $\mathrm{L}_{\mathrm{eq}}$ - were measured according to the Brazilian standard for noise assessment in urban environments, NBR 10151 [39], at various points along the railway line. In addition to the $\mathrm{L}_{\mathrm{eq}}$, the maximum and minimum noise levels were measured. A Brüel and Kjaer 4231 sound calibrator and five Type 1 integrating sound pressure level (SPL) meters (Brüel and Kjaer B\&K 2270, B\&K 2260 (two of this model), $B \& K 2250$ and $B \& K$ 2238) were used for the noise measurements.

Advances in computational resources have led to the development of several software programs for analyzing environmental noise pollution [40]. The SoundPLAN Version 6.2 software package was used in this study for the calculations involved in noise mapping to evaluate

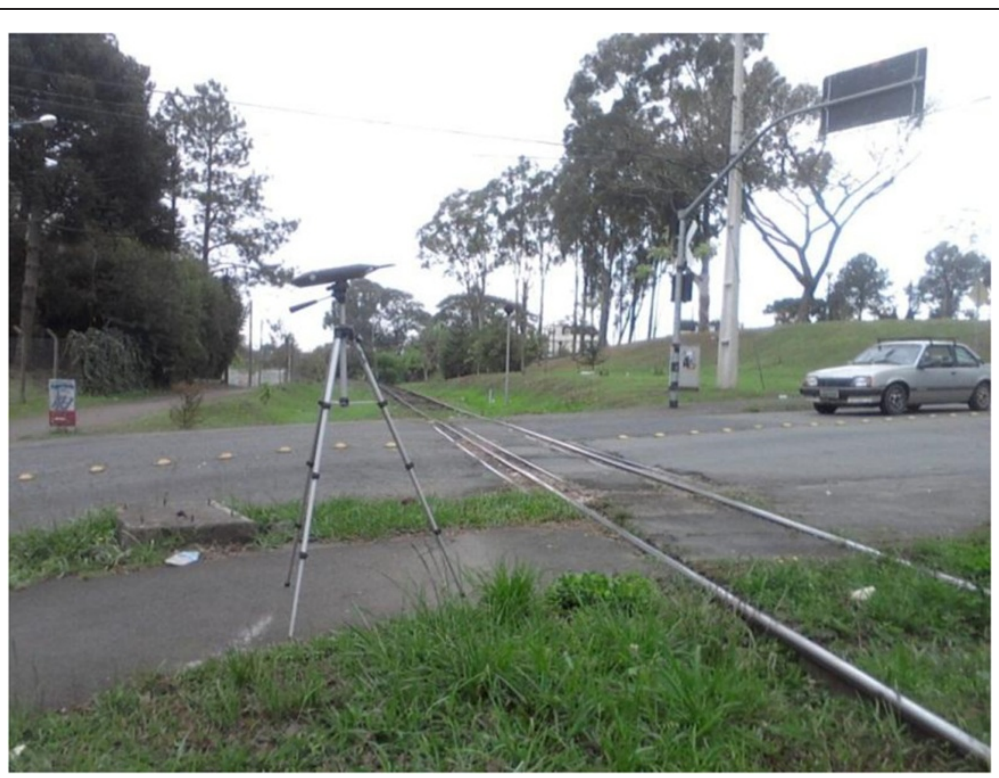

Figure 4 Urban street railroad crossing without safety barriers. 

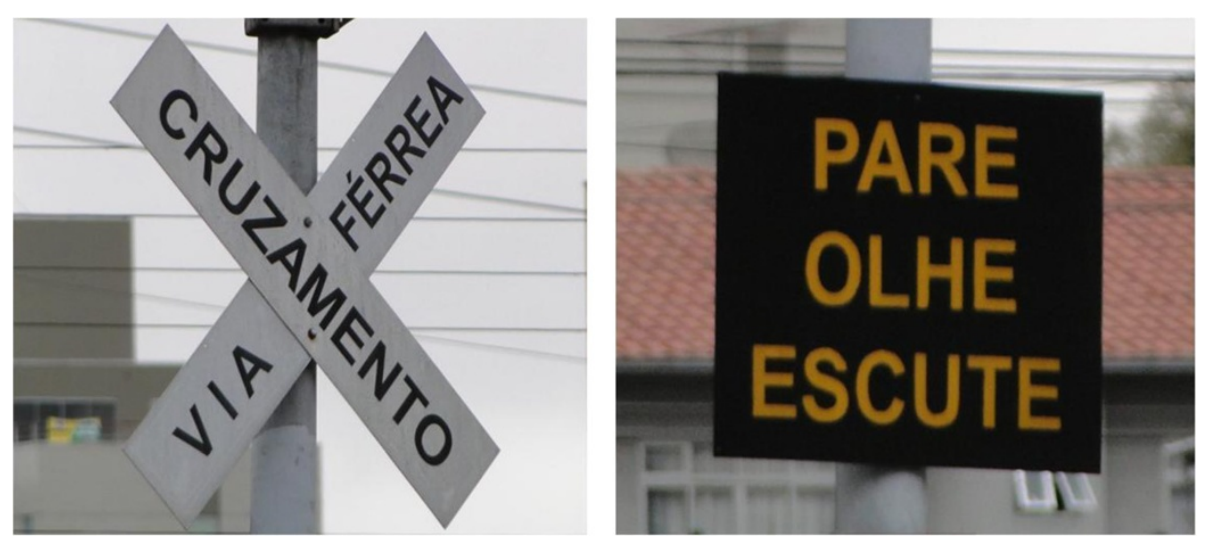

Figure 5 Safety signs warning of urban street railway crossings. Left: RAILWAY/CROSSING; Right: warning sign, from top to bottom: STOP/LOOK/LISTEN.

the noise levels caused by the railway. The current literature contains several studies which used noise mapping as a tool for environmental impact assessment (see, for instance [41-44].

The German prediction method for railway noise, Schall 03, was used to calculate the noise generated by trains $[34,45]$. In this method, the Mean Emission Level MEL can be calculated in two ways: 1) From the data flow, and 2) From data entered directly into the software, e.g., noise measurements [45]. In this study, noise mapping was performed by entering the measured noise levels as input data in the software. After entering this data, specific corrections must be made for the MEL, considering, among other factors, type of track, bridges, and railroad crossings.

To simulate the noise levels emitted by train horns, measurements were taken in situ, to enter them as input data into the software. After entering the railway data into the software SoundPlan, an area of calculation must be chosen with a given certain grid (average number of calculation points). For an environment that is little urbanized, a grid spacing of 20 to 50 meters suffices for acoustic mapping. However, for a highly urbanized region, the handbook of the software SoundPlan, indicate that the grid spacing may vary from 5 to 15 meters. The grid adopted in this work was $5 \times 5$ meters in order to produce a higher level of detail of the noise levels on the acoustic map. The height of the grid used in the calculation, as well as by other authors was 4 meters.

The simulated data were calibrated by placing a receiver point at the site where each noise measurement was taken. Measured and simulated levels were compared at the same height, in this specific case, $1.2 \mathrm{~m}$. The calibration was based on the recommendations of the European Commission Working Group - Assessment of Exposure to Noise [46], for which the expected uncertainty is $4.6 \mathrm{~dB}(\mathrm{~A})$ [47] when measured and simulated values are compared.

The steps taken to simulate rail noise are shown in the flow diagram shown in Figure 6.

To assess the degree of annoyance due to noise generated by the train traffic, interviews were conducted with the residents of neighborhoods that are crossed by the railway line. The researchers handed a questionnaire to each household. One person per household responded to the questionnaire. After two weeks the researchers collected the questionnaires. One hundred and fifty questionnaires were distributed, and 130 were collected. This research was performed according to the Helsinki Declaration.

\section{Results and discussions}

The trains passing though the city of Curitiba follow a pattern that is repeated at each railroad crossing. Shortly before reaching each crossing, the train blows its horn three times. Ten railroad crossings were evaluated, and noise measurements were taken at each of them in three different situations: A) Train passing with horn blowing, B) Train passing without horn blowing, and C) Surroundings of the railroad crossing without the presence of the train.

Figure 7 shows an example of a railroad crossing where a set of measurements were taken along the railroad, as described above. Each railroad crossing was assigned a number from 1 to 10 , and the three different measurement situations were assigned a subindex (A, B, and C).

Table 1 describes the noise level measurements at various points along the railway line, for the situations described in Figure 7.

The simulated data were calibrated by placing a receiver point at the site where each noise measurement 


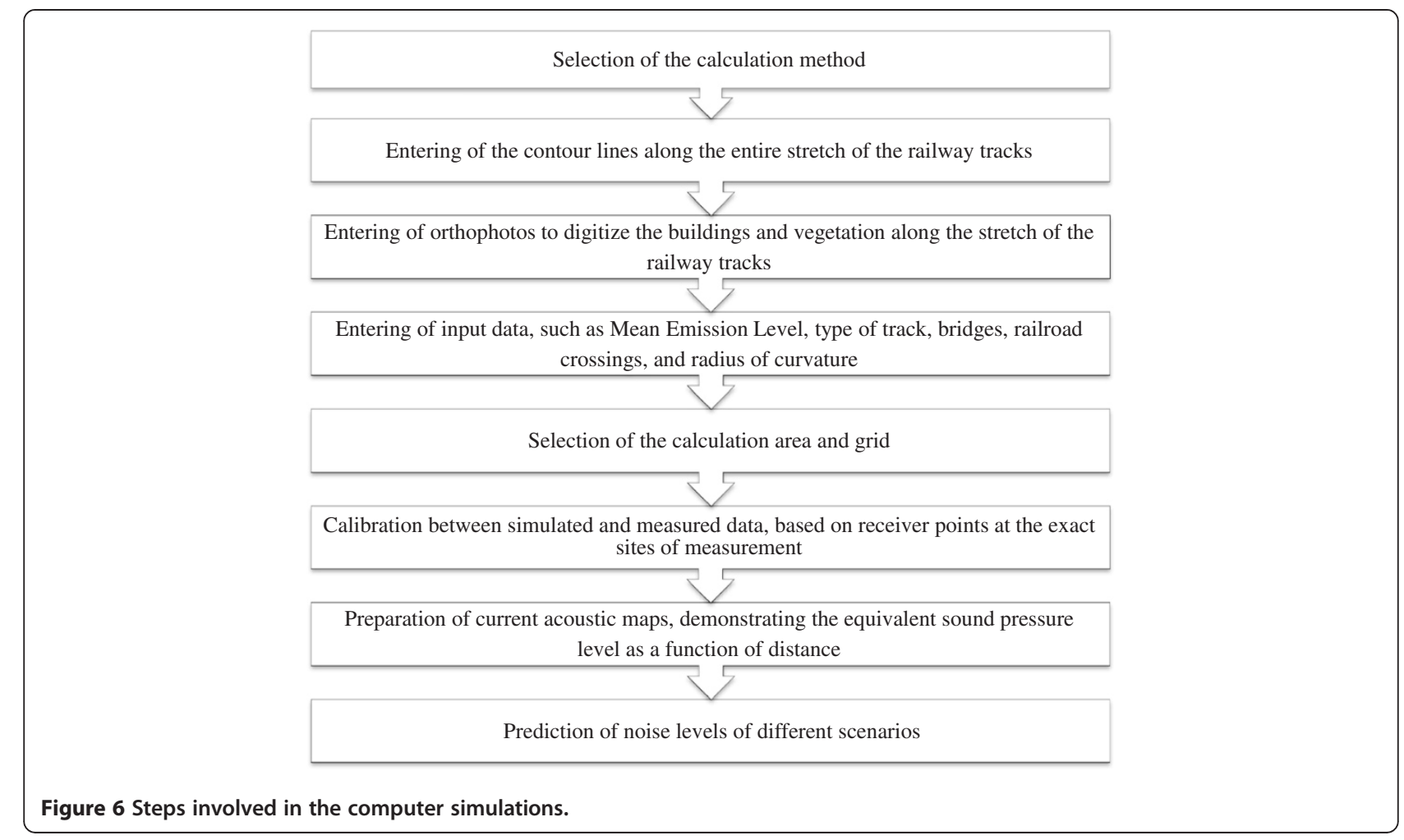

was taken. Measured and simulated noise levels were compared at the same height, in this specific case, $1.2 \mathrm{~m}$.

The calibration was based on the recommendations of Licitra and Memoli [47], whereby it is expected that the difference between the simulated and measured noise level does not exceed the value of $4.6 \mathrm{~dB}(\mathrm{~A})$.
Based on the above, Table 2 shows the measured noise levels and the noise levels calculated by the software SoundPLAN. As can be seen in Table 2, last column to the right, the differences between simulated and measured values was below $4.6 \mathrm{~dB}(\mathrm{~A})$, as recommended by Licitra and Memoli [47].

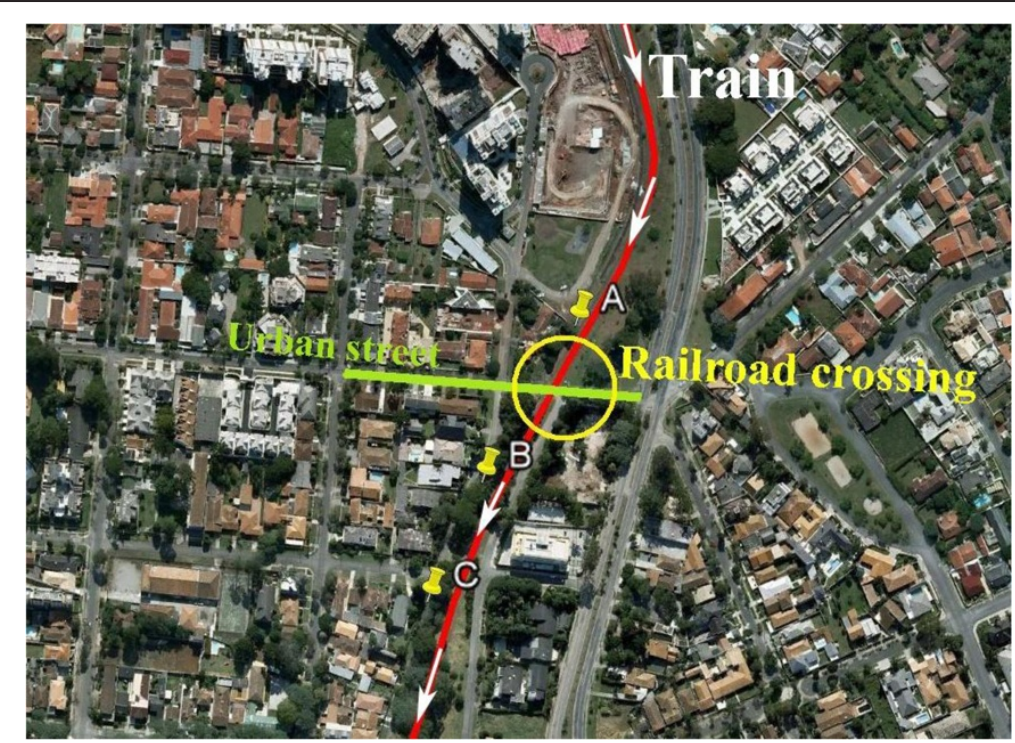

Figure 7 Measurement points along the railway line: A - Train passing with horn blowing, B - Train passing without horn blowing, $\mathrm{C}$ - Ambient noise without train passing. 
Table 1 Noise levels measured along the railroad and surroundings

\begin{tabular}{|c|c|c|c|c|c|}
\hline $\begin{array}{l}\text { Measurement site - } \\
\text { Railway crossing - }\end{array}$ & Measurement situation & Characterization of the measurement & $L_{\min } d B(A)$ & $L_{e q} d B(A)$ & $\mathrm{L}_{\max } \mathrm{dB}(\mathrm{A})$ \\
\hline \multirow[t]{3}{*}{1} & A & Train passing with horn blowing & 90.1 & 108.3 & 121.4 \\
\hline & B & Train passing without horn blowing & 62.4 & 79.8 & 91.0 \\
\hline & C & Ambient noise without train passing & 48.3 & 59.9 & 76.2 \\
\hline \multirow[t]{3}{*}{2} & A & Train passing with horn blowing & 71.3 & 101.0 & 108.3 \\
\hline & B & Train passing without horn blowing & 49.9 & 79.9 & 91.4 \\
\hline & C & Ambient noise without train passing & 41.9 & 53.9 & 75.7 \\
\hline \multirow[t]{3}{*}{3} & A & Train passing with horn blowing & 74.5 & 109.8 & 115.6 \\
\hline & B & Train passing without horn blowing & 60.0 & 80.0 & 93.4 \\
\hline & C & Ambient noise without train passing & 46.5 & 59.4 & 78.6 \\
\hline \multirow[t]{3}{*}{4} & A & Train passing with horn blowing & 69.4 & 102.7 & 109.7 \\
\hline & B & Train passing without horn blowing & 66.2 & 87.4 & 95.7 \\
\hline & C & Ambient noise without train passing & 43.1 & 53.6 & 72.9 \\
\hline \multirow[t]{3}{*}{5} & A & Train passing with horn blowing & 86.2 & 108.9 & 115.1 \\
\hline & B & Train passing without horn blowing & 66.5 & 84.3 & 90.9 \\
\hline & C & Ambient noise without train passing & 50.3 & 57.9 & 73.0 \\
\hline \multirow[t]{3}{*}{6} & A & Train passing with horn blowing & 77.8 & 108.9 & 115.6 \\
\hline & B & Train passing without horn blowing & 77.1 & 82.5 & 89.4 \\
\hline & C & Ambient noise without train passing & 45.7 & 59.7 & 84.7 \\
\hline \multirow[t]{3}{*}{7} & A & Train passing with horn blowing & 61.1 & 100.0 & 109.9 \\
\hline & B & Train passing without horn blowing & 71.6 & 80.8 & 87.0 \\
\hline & C & Ambient noise without train passing & 55.0 & 70.5 & 87.0 \\
\hline \multirow[t]{3}{*}{8} & A & Train passing with horn blowing & 78.5 & 108.1 & 116.5 \\
\hline & B & Train passing without horn blowing & 73.6 & 81.6 & 90.9 \\
\hline & C & Ambient noise without train passing & 54.6 & 65.7 & 80.4 \\
\hline \multirow[t]{3}{*}{9} & A & Train passing with horn blowing & 67.2 & 105.9 & 112.6 \\
\hline & B & Train passing without horn blowing & 64.9 & 82.3 & 93.4 \\
\hline & C & Ambient noise without train passing & 51.4 & 62.7 & 86.4 \\
\hline \multirow[t]{3}{*}{10} & A & Train passing with horn blowing & 53.8 & 95.0 & 111.4 \\
\hline & B & Train passing without horn blowing & 67.1 & 77.5 & 93.4 \\
\hline & C & Ambient noise without train passing & 51.9 & 60.6 & 75.6 \\
\hline
\end{tabular}

The railroad crossings listed in Table 1 are located in Urban Residential Areas for which Law 10625 of the municipality of Curitiba [48], which enacts laws about urban noise, establishes that daytime noise levels, from 7:01 a.m. to 7:00 p.m., should not exceed $55 \mathrm{~dB}(\mathrm{~A})$. Thus, it is evident that the noise generated by passing trains exceeds the limits established by municipal legislation, resulting in noise pollution.

To analyze the noise generated by rail traffic based not only on measurements, SoundPLAN software was used to calculate noise maps for two situations: 1) Train passing with horn blowing, 2) Train passing without horn blowing. The results obtained from these simulations indicate how high the noise levels are. Figure 8 show the noise map in three dimensions, of when a train passes with its horn blowing.

The map in the above figure show that the passage of trains blowing their horns generates noise levels of 80 to $92 \mathrm{~dB}(\mathrm{~A})$ at the facades of the homes closest to the railway line. Moreover, they indicate that the noise levels that reach the more distant homes range from 68 to 80 $\mathrm{dB}(\mathrm{A})$. Figure 8 also indicates that together with the train, the noise levels at the centerline of the noise map exceed $96 \mathrm{~dB}(\mathrm{~A})$. The noise maps were calculated based on railroad crossing no. 2 and measurement situation "A," as indicated in Tables 1 and 2.

Curitiba's urban legislation [48] establishes a maximum daytime noise level of $55 \mathrm{~dB}(\mathrm{~A})$ for the area of 
Table 2 Comparison of measured and simulated noise levels

\begin{tabular}{|c|c|c|c|c|}
\hline $\begin{array}{l}\text { Measurement site along } \\
\text { the railway lines }\end{array}$ & $\begin{array}{l}\text { Measurement } \\
\text { situation }\end{array}$ & $\begin{array}{l}\text { Measured } \\
L_{\text {eq }} d B(A)\end{array}$ & $\begin{array}{l}\text { Simulated } \\
L_{e q} d B(A)\end{array}$ & $\begin{array}{l}\text { Difference between measured } \\
\text { and simulated noise }\end{array}$ \\
\hline \multirow[t]{2}{*}{1} & $A$ & 108.3 & 107.5 & 0,8 \\
\hline & B & 79.8 & 80.3 & $-0,5$ \\
\hline \multirow[t]{2}{*}{2} & A & 101.0 & 100.2 & 0,8 \\
\hline & B & 79.9 & 79.3 & 0,6 \\
\hline \multirow[t]{2}{*}{3} & A & 109.8 & 111.1 & $-1,3$ \\
\hline & B & 80.0 & 81.5 & $-1,5$ \\
\hline \multirow[t]{2}{*}{4} & A & 102.7 & 103.2 & $-0,5$ \\
\hline & B & 87.4 & 88.2 & $-0,8$ \\
\hline \multirow[t]{2}{*}{5} & A & 108.9 & 108.3 & 0,6 \\
\hline & B & 84.3 & 84.7 & $-0,4$ \\
\hline \multirow[t]{2}{*}{6} & A & 108.9 & 108.4 & 0,5 \\
\hline & B & 82.5 & 83.1 & $-0,6$ \\
\hline \multirow[t]{2}{*}{7} & A & 100.0 & 100.7 & $-0,7$ \\
\hline & B & 80.8 & 82.8 & $-2,0$ \\
\hline \multirow[t]{2}{*}{8} & A & 108.1 & 109.2 & $-1,1$ \\
\hline & B & 81.6 & 83.3 & $-1,7$ \\
\hline \multirow[t]{2}{*}{9} & A & 105.9 & 104.3 & 1,6 \\
\hline & B & 82.3 & 82.9 & $-0,6$ \\
\hline \multirow[t]{2}{*}{10} & A & 95.0 & 95.6 & $-0,6$ \\
\hline & B & 77.5 & 76.9 & 0,6 \\
\hline
\end{tabular}

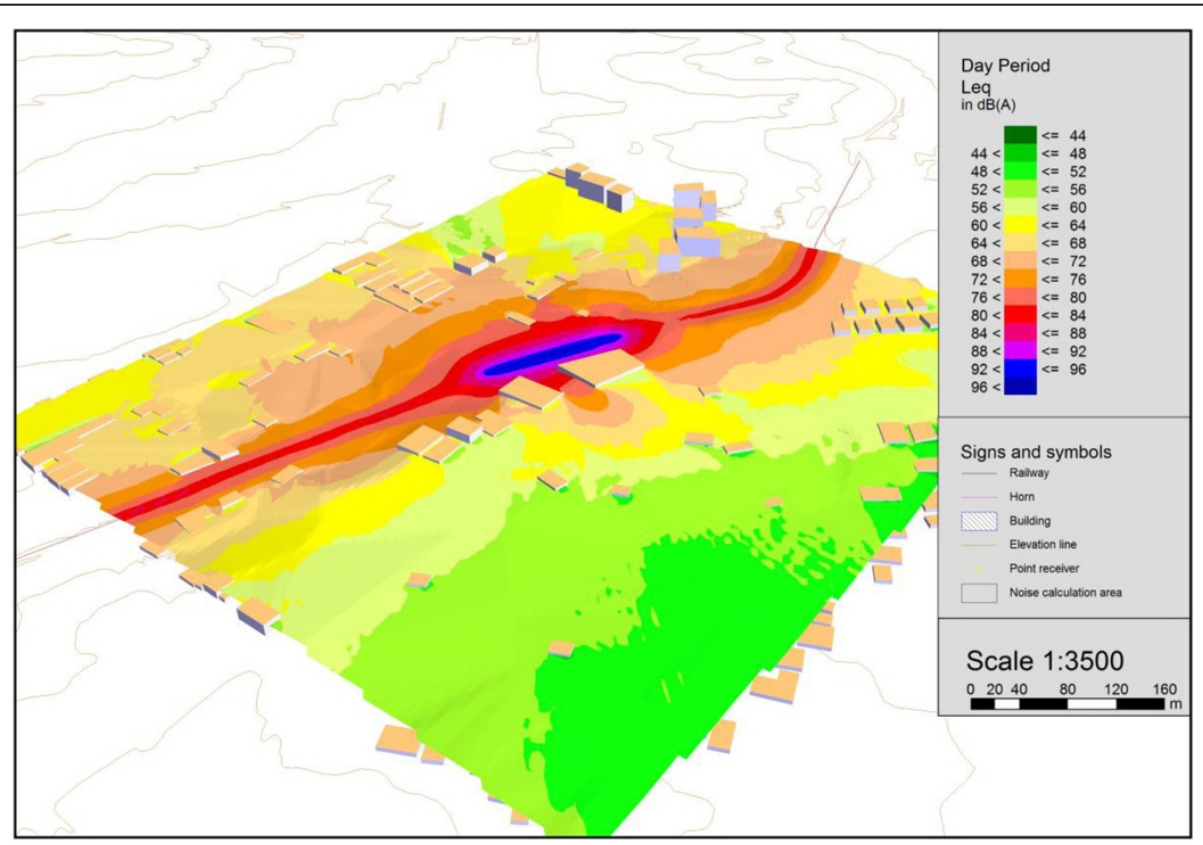

Figure $83 \mathrm{D}$ noise map of the situation when the train is blowing its horn. 
this study, which is a residential area. Therefore, the situation is clearly one of noise pollution, since the noise levels generated far exceed the legally established limit. It should be kept in mind, as explained earlier, that trains pass through the city about ten times a day, blowing their horns about 1200 times as they approach the city's 40 railroad crossings.

The map in Figure 9, show the scenario when the train does not blow its horn. The noise emission level decreases significantly with the elimination of the blowing horn. The noise levels in the proximities of the rail line vary from 68 to $80 \mathrm{~dB}(\mathrm{~A})$, in contrast with the situation with the horn blowing, when the levels varied from 80 to $92 \mathrm{~dB}(\mathrm{~A})$.

The noise maps indicate the efficiency of this noise control measure, the elimination of the blowing horn. However, it is also clear that although the noise levels are drastically reduced, they still exceed the noise limits established by municipal legislation.

The analysis of questionnaires filled out by residents indicated that they are well aware of the problem of noise generated by the trains, since the majority, $62 \%$, have lived there for one to five years, and $25 \%$ have lived there for over five 5 years. Only $18 \%$ of the respondents have lived there for less than a year.

Residents were asked to assess whether - during the time they have lived there - the noise has increased, remained the same or decreased. Among the respondents, $65 \%$ indicated that the noise has increased, 33\% indicated that the noise has remained the same, and only
$2 \%$ stated that it has decreased. With regard to the intensity of noise, $57 \%$ classified it as very intense, $35 \%$ as intense, and $8 \%$ as little intense.

When asked if the noise in the neighborhood bothers them, $84 \%$ answered YES, $15 \%$ answered NO, and 1\% did not answer the question. Asked if they believe that environmental noise is harmful to their health, $98 \%$ of the residents answered YES and only $2 \%$ answered NO.

Residents were asked whether - they find the noise irritating, to which 92\% answered YES and 8\% NO. Table 3 lists the noises considered sources of irritation to residents that answered YES to the question: "Is this noise source a cause of irritation?"

The residents were asked whether noise leads to - poor concentration, to which $86 \%$ said YES, $13 \%$ answered NO, and $1 \%$ did not respond. Table 4 lists the noise sources that interfere with concentration, for residents who answered $Y E S$ when asked: "Does this source of noise lead to poor concentration?"

Residents were asked whether the noise causes headache, to which 59\% responded YES, 39\% answered $N O$, and $2 \%$ did not respond. Table 5 lists the noise sources causing headaches in residents who answered $Y E S$ to the question: "Does noise give you headaches?"

The residents were asked what time of the day they consider the most bothersome in terms of noise. The great majority, $88 \%$, stated that the most bothersome time is the nighttime. Asked if the noise causes them insomnia, $73 \%$ of the respondents answered YES, and $27 \%$ NO.

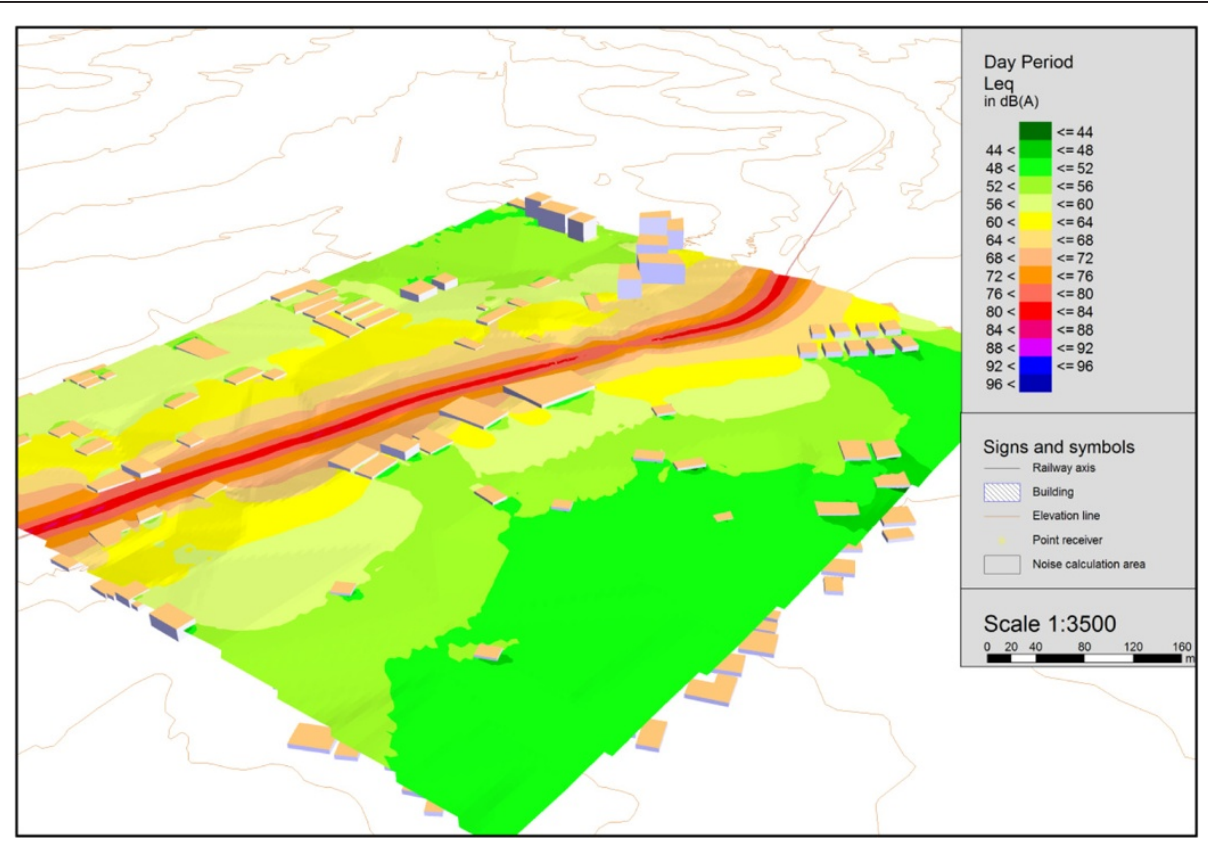

Figure 9 3D noise map of the train passing without blowing its horn. 
Table 3 Noise as a cause of irritation and percent of interviewees affected by it

\begin{tabular}{lc}
\hline $\begin{array}{l}\text { Sources of noise that } \\
\text { cause irritation }\end{array}$ & $\begin{array}{c}\text { Respondents that } \\
\text { answered yes }\end{array}$ \\
\hline Automotive vehicles & $52 \%$ \\
Trains & $95 \%$ \\
Churches and temples & $2 \%$ \\
Fireworks & $10 \%$ \\
Animals & $9 \%$ \\
Toys and games & $1 \%$ \\
Construction sites & $34 \%$ \\
Noisy neighbors & $26 \%$ \\
Nightclubs & $3 \%$ \\
Others & $6 \%$ \\
\hline
\end{tabular}

The respondents who answered YES when asked whether noise caused insomnia were asked to point out the main sources causing insomnia. Table 6 lists the noise sources that cause insomnia in residents who responded $Y E S$ to the question: "Does noise interfere in your sleep?"

The interviewees were asked how frequently - their sleep is disrupted by noise, to which 58\% answered Often, $32 \%$ Sometimes, 9\% Never, and $1 \%$ did not answer. They were then asked whether - sleep is interrupted by the noise of the train, with $70 \%$ claiming that their sleep is Interrupted Frequently, 21\% Sometimes 8\% Rarely or Never, and $1 \%$ did not answer.

Table 7 lists the times of the day when, according to the residents, the noise of the train is the most frequent nuisance.

As reported above, $88 \%$ of the interviewees indicated that the noise of the train is the most annoying during the nighttime. In view of this finding, measurements

Table 4 Noise causing poor concentration and percent of interviewees affected by it

\begin{tabular}{lc}
\hline $\begin{array}{l}\text { Sources of noise that cause } \\
\text { poor concentration }\end{array}$ & $\begin{array}{c}\text { Respondents that } \\
\text { answered yes }\end{array}$ \\
\hline Automotive vehicles & $57 \%$ \\
Trains & $\mathbf{8 8} \%$ \\
Churches and Temples & $4 \%$ \\
Fireworks & $13 \%$ \\
Animals & $9 \%$ \\
Toys and games & $4 \%$ \\
Construction sites & $31 \%$ \\
Noisy neighbors & $22 \%$ \\
Nightclubs & $5 \%$ \\
Others & $5 \%$ \\
\hline
\end{tabular}

Table 5 Noise as a cause of headaches and percent of interviewees affected by it

\begin{tabular}{lc}
\hline $\begin{array}{l}\text { Sources of noise that } \\
\text { cause headaches }\end{array}$ & $\begin{array}{c}\text { Respondents that } \\
\text { answered yes }\end{array}$ \\
\hline Automotive vehicles & $53 \%$ \\
Trains & $96 \%$ \\
Churches and temples & $3 \%$ \\
Fireworks & $6 \%$ \\
Animals & $6 \%$ \\
Toys and games & $3 \%$ \\
Construction sites & $23 \%$ \\
Noisy neighbors & $18 \%$ \\
Nightclubs & $4 \%$ \\
Others & $3 \%$ \\
\hline
\end{tabular}

were taken of the nighttime noise generated by passing trains. To this end, a sound level meter was installed in a sound receiving location - the home of a resident. The distance from the railway tracks to the receiver site (the resident's home) is about 200 meters. As Figure 10 shows, the measurements started before 10 p.m. and ended after 6 a.m. A B\&K 2238 sound level meter was used and the measurements were taken with a datalog module (noise levels vs. time of measurement), with measurements recorded at 10 minute intervals.

Figure 10 indicates that two trains passed by the measurement location between 10 p.m. and 6 a.m., one at 10:10 p.m. and the other at 6:20 a.m. Both trains blew their horn, as evidenced by the high values of maximum sound level, $\mathrm{L}_{\max }$, and equivalent sound level, $\mathrm{L}_{\text {eq }}$.

Figure 10 shows how high the noise level is when a train passes with its horn blowing, since the maximum sound levels reached nearly $80 \mathrm{~dB}(\mathrm{~A})$ at the railroad crossing at 10:10 p.m. and $78 \mathrm{~dB}(\mathrm{~A})$ at 6:20 a.m. The

Table 6 Noise causing insomnia and percentage of respondents affected by it

\begin{tabular}{lc}
\hline $\begin{array}{l}\text { Sources of noise } \\
\text { causing insomnia }\end{array}$ & $\begin{array}{c}\text { Respondents that } \\
\text { answered yes }\end{array}$ \\
\hline Automotive vehicles & $61 \%$ \\
Trains & $100 \%$ \\
Churches and temples & $1 \%$ \\
Fireworks & $11 \%$ \\
Animals & $9 \%$ \\
Toys and games & $1 \%$ \\
Construction sites & $29 \%$ \\
Noisy neighbors & $25 \%$ \\
Nightclubs & $4 \%$ \\
Others & $4 \%$ \\
\hline
\end{tabular}


Table 7 Time of the day when the train's noise is the most annoying and percentage of respondents affected by it

\begin{tabular}{lc}
\hline $\begin{array}{l}\text { Time when sleep is interrupted } \\
\text { by train noise }\end{array}$ & $\begin{array}{c}\text { Percentage of } \\
\text { respondents }\end{array}$ \\
\hline $12-2$ a.m. & $18 \%$ \\
$2-4$ a.m. & $18 \%$ \\
$\mathbf{4}-\mathbf{6}$ a.m. & $37 \%$ \\
$\mathbf{6}-\mathbf{8}$ a.m. & $43 \%$ \\
8 - 10 a.m. & $19 \%$ \\
10 a.m. 12 p.m. & $2 \%$ \\
$12-2$ p.m. & $1 \%$ \\
$2-4$ p.m. & $0 \%$ \\
$4-6$ p.m. & $0 \%$ \\
6 - 8 p.m. & $3 \%$ \\
8 - 10 p.m. & $9 \%$ \\
$\mathbf{1 0}$ p.m. $-\mathbf{1 2}$ a.m. & $35 \%$ \\
\hline
\end{tabular}

equivalent sound pressure level reached $\mathrm{L}_{\mathrm{eq}}=60 \mathrm{~dB}(\mathrm{~A})$ at 10:10 p.m. and $\mathrm{L}_{\mathrm{eq}}=58 \mathrm{~dB}(\mathrm{~A})$ at 6:20 a.m.

Curitiba's municipal Law 10625, which regulates noise in communities [49], establishes that the noise levels, $\mathrm{L}_{\text {eq }}$, from 10 p.m. to 7 a.m. cannot exceed $45 \mathrm{~dB}(\mathrm{~A})$ in the region where the nighttime measurements were taken. Therefore, it is a clear violation of this law during the nighttime.

The measurement shown in Figure 10 proves what the residents claimed, as indicated in Table 7 , i.e., the daytime periods from 4 to $6 \mathrm{a}$.m. and 6 to $8 \mathrm{a}$.m., and the nighttime period from $10 \mathrm{p} . \mathrm{m}$. to midnight are the periods of greatest annoyance due to train noise. $37 \%$ of the respondents stated that the noise between 4 and 6 a.m. was the most annoying, while 43\% stated it was between 6 and
8 a.m., and 35\% claimed that the noise between 10 p.m. and midnight was the most disruptive.

Lastly, the residents were asked whether they believe that local noise can devalue their home, to which $69 \%$ responded $Y E S, 28 \% N O$, and $3 \%$ did not answer the question.

Evaluating the effect of aircraft noise on home value depreciation, Espey and Lopez [50] showed that the value of homes located in areas close to an airport, where noise levels were $65 \mathrm{~dB}(\mathrm{~A})$ or higher, was about \$ 2400 lower than similar homes located in areas not considered noisy. Railway noise also has an impact on the value of homes. The train horn is considered a major cause of high noise levels near railway lines. Bellinger [49] evaluated the cost of noise generated by blowing train horns in a small town in Pennsylvania. According to him, real estate market values depreciate by $4.1 \%$ for every $10 \mathrm{~dB}$ above the background noise level. Considering the 256 homes affected, the losses represented a total of about \$ 4 million in 2004 market values.

\section{Conclusions}

The present study evaluated the noise generated by railway in a large Latin American city. Several analytical techniques were used - measurements of noise levels during the passage of the train with and without its horn blowing, measurement of noise levels in the home of a resident affected by the noise of the train and calculation of noise mapping. Lastly, to assess the degree of annoyance due to noise generated by train, interviews were conducted with the residents of neighborhoods that are crossed by the railway line.

As in the study presented here, research conducted in Poland by Szwarc et al. [51], and in Germany by Czolbe [52] also used noise maps to diagnose the impact of noise generated by railway traffic in urban areas.

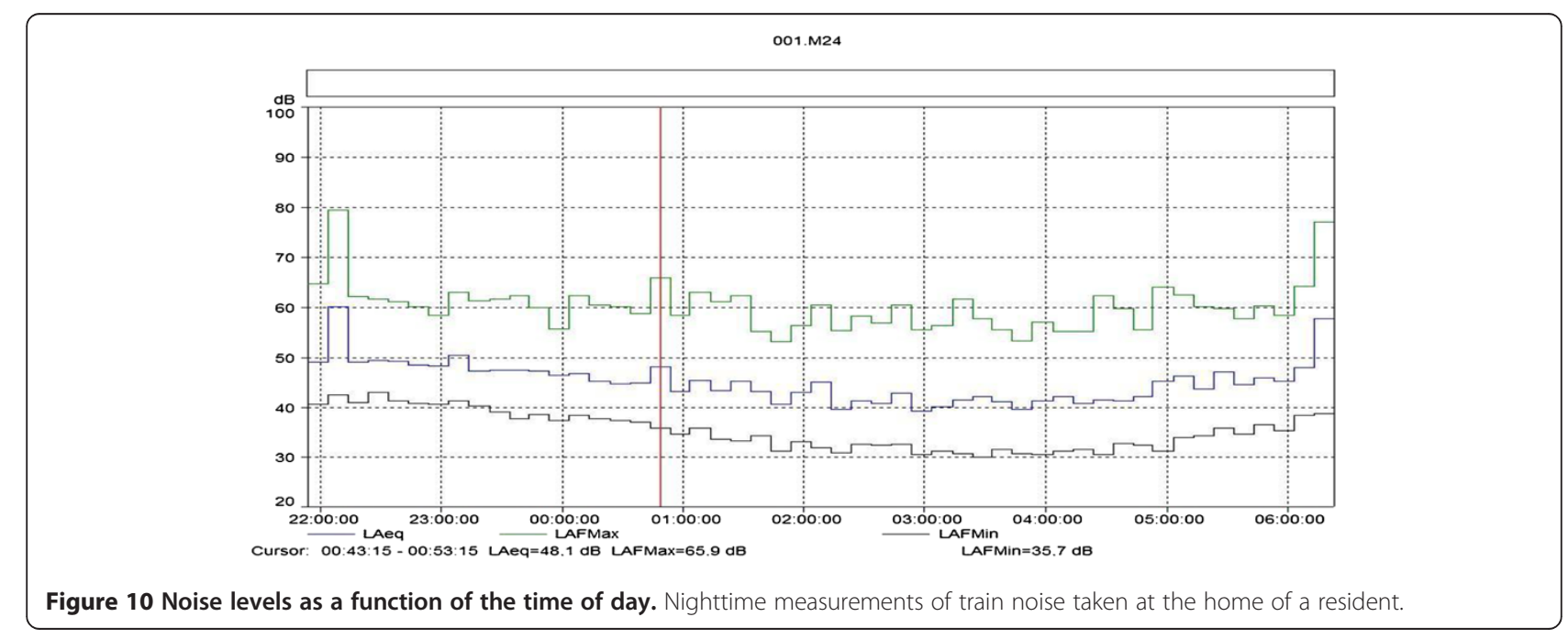


The measurements indicated that the noise levels generated as the train passes with its horn blowing are extremely high, clearly violating Curitiba's noise legislation. The noise mappings showed that a simple solution to control noise would be for the trains to pass through the city without blowing their horns. However, although the noise levels are significantly lower when the train's horn is not blown, they still exceed the levels established by municipal legislation.

The city has been suffering from this problem for decades. The solution to the problem would be to remove the railway line passing through the city. However, lack of resources and of political will are two obstacles to the removal of the trains passing through residential areas within the city.

The residents were found to feel strongly affected by noise generated by passing trains. Train noise causes irritation and annoyance, headaches, poor concentration and insomnia. In terms of noise pollution, $88 \%$ of the respondents cited nighttime as the most critical time of the day. As shown in this paper, the research of Fields and Walker [22] in Great Britain, Lambert et al. [16] in France, and Ali [53] in Egypt also show that the population neighboring railways feels disturbed by the noise of the train.

This study showed that the vast majority of residents surveyed (69\%), believe that the noise of the train can devalue their property. We would do well to keep in mind the words of Fields and Walker [22]: "Noise is rated as the most serious environmental nuisance caused by railways."

\section{Competing interests}

The authors declare that they have no competing interests.

\section{Authors' contributions}

Both authors participated in the planning and performance of the measurements and simulations. Both authors contributed equally to the writing of the manuscript. Both authors read and approved the final manuscript.

\section{Aknowledgments \\ The authors gratefully acknowledge the German Government, through the German Academic Exchange Service - DAAD (Deutscher Akademischer Austauschdienst) and the Brazilian Government, through the National Council for Scientific and Technological Development - CNPq, for their financial support, which enabled the purchase of the sound level meters and software used in this study. The authors would like to thank the reviewers who contributed to the improvement of this work with their observations.}

Received: 24 March 2013 Accepted: 22 October 2013

Published: 8 January 2014

\section{References}

1. Griffiths ID, Langdon FJ: Subjective response to road traffic noise. J Sound Vib 1968, 8(1):16-32.

2. Lercher P, Evans GW, Meis M: Ambient noise and cognitive processes among primary schoolchildren. Environ Behav 2003, 35(6):725-735.

3. Zannin PHT, Szeremetta B: Avaliação da poluição sonora no parque Jardim Botânico de Curitiba, Paraná. Brasil. Cadernos de Saúde Púb 2003, 19(2):683-686 (in Portuguese).
4. Abo-Qudais S, Abu-Qdais $\mathrm{H}$ : Perception and attitudes of individuals exposed to traffic noise in working places. Build Environ 2005, 40(6):778-787.

5. Díaz C, Pedrero A: Sound exposure during daily activities. Appl Acoust 2005, 67:271-283.

6. Zannin PHT, Marcon CR: Objective and subjective evaluation of the acoustic comfort in classrooms. Appl Ergon 2007, 38:675-680.

7. Zannin PHT, Zwirtes DPZ: Evaluation of the acoustic performance of classrooms in public schools. Appl Acoust 2009, 70:626-635.

8. Haka M, Haapakangas A, Keränen J, Hakala J, Keskinen E, Hongisto V: Performance effects and subjective disturbance of speech in acoustically different office types - a laboratory experiment. Indoor Air 2009, 19:454-467.

9. Golmohammadi R, Ghorbani F, Mahjub H, Daneshmehr Z: Study of school noise in the capital city of Tehran-Iran. Iran. J. Environ. Health. Sci. Eng. 2010, 7(4):365-370.

10. Zannin PHT, Ferreira AMC: Field measurements of acoustic quality in university classrooms. J of Sci \& Industrial Res 2009, 68:1053-1057.

11. Goswami S: Road Traffic Noise: A Case Study of Balasore Town, Orissa. India. Inter J of Environmental Res 2009, 3(2):309-316.

12. Mohammadi G: An investigation of community response to urban traffic noise. Iran. J. Environ. Health. Sci. Eng. 2009, 6(2):137-142.

13. Alimohammadi I, Soltani R, Sandrock S, Azkhosh M, Gohari MR: The effects of road traffic noise on mental performance. Iranian J of Envi Health Sci \& Engr 2013, 10:18.

14. Zannin PHT, Engel MS, Fiedler PEK, Bunn F: Characterization of environmental noise based on noise measurements, noise mapping and interviews: A case study at a university campus in Brazil. Cities 2013, 31:317-327.

15. da Paz EC, Ferreira AMC, Zannin PHT: Comparative study of the perception of urban noise (Estudo comparativo da percepção do ruído urbano). Revista de Saúde Pública (J of Public Health) 2005, 39(3):467-472 (in Portuguese).

16. Lambert J, Champelovier $P$, Vernet I: Annoyance from high speed train noise: A social survey. J Sound Vib 1996, 193:21-28.

17. Yano T, Yamashita T, Izumi K: Comparison of community annoyance from railway noise evaluated by different category scales. J Sound Vib 1997, 205:505-511.

18. de Jong RG, Miedema HME: Is freight traffic noise more annoying than passenger traffic noise? J Sound Vib 1996, 193:35-38.

19. Franssen EAM, Staatsen BAM, Lebret E: Assessing health consequences in an environmental impact assessment: the case of Amsterdam Airport Schiphol. Environ Impact Assess Rev 2002, 22(6):633-653.

20. Fyhri A, Aasvang GM: Noise, sleep and poor health: Modeling the relationship between road traffic noise and cardiovascular problems. Sci of The Total Environ 2010, 408(21):4935-4942.

21. Seidman MD, Standring RT: Noise and Quality of Life. Int. J. Environ. Res. and Public Health 2010, 7:3730-3738.

22. Fields JM, Walker JG: The response to railway noise in residential areas in Great Britain. J Sound Vib 1982, 85:177-255.

23. Öhrström E, Skånberg A-B: A field survey on effects of exposure to noise and vibration from railway traffic, PART I: Annoyance and activity disturbance effects. J Sound Vib 1996, 193:39-47.

24. Zannin PHT, Calixto A, Diniz FBD, Ferreira JAC, Schulle R: Incômodo Causado pelo Ruído Urbano à População de Curitiba, PR. [Annoyance Caused by Urban Noise to the Citizens of Curitiba, PR]. Rev Saude Publica 2002, 36(4):521-524. in Portuguese.

25. Szeremeta B, Zannin PHT: Analysis and evaluation of soundscapes in public parks through interviews and measurement of noise. Sci Total Environ 2009, 407:6143-6149.

26. Mansouri N, Pourmahabadian M, Ghasemkhani M: Road traffic noise in downtown area of Tehran. Iranian J of Envi Health Sci \& Engr 2006, 3(4):267-272.

27. da Paz EC, Zannin PHT: Urban daytime traffic noise prediction models. Environ Monit Assess 2010, 163:515-529.

28. ANTT-Agência Nacional de Transportes Terrestres: Transporte de Cargas Transporte Ferroviário [ANTT-National Land Transport Agency. Freight Transportation - Rail Transportation; 2010. Available at: www.antt.gov.br/ carga/ferroviario/ferroviario.asp Accessed on 15 Nov 2011 (in Portuguese).

29. CIA: Central Intelligence Agency. Washington, DC: The World Factbook 2011; 2011. https://www.cia.gov/library/publications/theworldfactbook/rankorder/ 
2121 rank.html?country Name=Brazil\&countryCode=br\&regionCode=soa\& rank=10\#br. Accessed on 30 May 2012.

30. Brasil (2011). Corredor Bioceânico Ferroviário: Estudos técnicos referentes ao Eixo de Capricórnio: Relatório Consolidado. Trabalho realizado com recursos do Fundo de Estruturação de Projetos do BNDES. [Bioceanic Railway Corridor: Technical studies for the Capricorn Hub. Consolidated. in Portugue: ReportWork performed with resources from the Project Structuring Fund of BNDES] Híbrida; 2011.

31. Janssen G: Monitoring and predicting railway noise and its large-scale impact on the environment: A tool for policy-makers. J of Sound and Vibration 1996, 193(1):253-260.

32. Omidvari M, Nouri J: Effects of noise pollution on traffic policemen. Int. J. Environ. Res 2009, 3(4):645-652.

33. Skanberg $A B$, Öhrström E: A field survey on effects of exposure to noise and vibration from railway traffic, Part I: Annoyance and activity disturbance effects. J of Sound and Vibration 1996, 193(1):39-47.

34. Moehler U, Liepert M, Schuemer R, Griefahn B: Differences between railway and road traffic noise. J of sound and vibration 2008, 231(3):853-864

35. Parizet $\mathrm{E}$, Hamzaoui $\mathrm{N}$, Jacquemound J: Noise assessment in a high-speed train. Appl Acoust 2002, 63:1109-1124.

36. Cushing-Daniels B, Murray P: Welfare effects of increased train noise: A comparison of the costs and benefits of train whistle use at highwayrailway crossings. Transp Res D 2005, 10:357-364.

37. Bertoli SR, de Paiva CEL: Exposição não ocupacional a ruído de passageiros de trens metropolitanos da grande São Paulo. in Portuguese: [Non-occupational exposure to noise of passengers in metropolitan trains in Greater São Paulo] 19th Meeting of the Brazilian Society of Acoustics; 2000.

38. Roland MM, Zannin PHT: Avaliação do ruído ferroviário em Curitiba. in Portuguese: [Assessment of rail noise in Curitiba] Proceedings of the 13th Scientific Initiation Event, Federal University of Paraná, Brazil; 2005.

39. NBR 10151: Associação Brasileira de Normas Técnicas [ABNT]. Rio de Janeiro: NBR 10.151: Avaliação do ruído em áreas habitadas visando o conforto da comunidade; 2000 (in Portuguese).

40. Kang J: Urban sound environment. London: Taylor and Francis; 2007.

41. Diniz FB, Zannin PHT: Noise impact by electrical energy substations in the city of Curitiba. Brazil. Sci Total Environ 2004, 328:23-31.

42. Pinto FAC, Mardones MDM: Noise mapping of densely populated neighborhoods - example of Copacabana Rio de Janeiro - Brazil. Environ Monit Assess 2009, 155:309-318.

43. Guedes ICM, Bertoli SR, Zannin PHT: Influence of urban shapes on environmental noise: A case study in Aracaju Brazil. Sci Total Environ 2011, 412:66-76.

44. Zannin PHT, de Sant'Ana DQ: Noise mapping at different stages of a freeway redevelopment project - A case study in Brazil. Appl Acoust 2011, 72(8):479-486.

45. Schall 03 - Deutsche Bundesbahn: Richtlinie zur Berechnung der Schallimmissionen von Schienenwegen. in German: Deutsche Bundesbahn Zentralamt, Munich, Schall 03/Akustik 03; 1990.

46. European Commission Working Group Assessment of Exposure to Noise (WGAEN): "Good Practice Guide for Strategic Noise Mapping and the Production of Associated Data on Noise Exposure" - version 2; 2006:1-129.

47. Licitra G, Memoli G: Limits and advantages of good practice guide to noise mapping. Forum Acusticum; 2008. June 29 - July 4, 2008, Paris, France [on CD - ISBN: 978-2-9521105-4-9; EAN: 9782952110549$].$

48. Prefeitura Municipal de Curitiba: Lei Municipal 10.625 de 19 de dezembro de 2002. Diário Oficial do Estado do Paraná: Dispõe sobre ruídos urbanos, proteção do bem estar e do sossego público e dá outras providências; 2002. in Portuguese.

49. Bellinger WK: The economic valuation of train horn noise: A US case Study. Transp Res D 2006, 11:310-314.

50. Espey M, Lopez $\mathrm{H}$ : The impact of airport noise and proximity on residential property values. Growth and Change 2000, 31:408-419.

51. Szwarc M, Kostek B, Kotus J, Szczodrak M, Czyzewski A: Problems with railway noise - A case study. Int J Occup Saf Ergon 2011, 17(3):309-325.

52. Czolbe C: Berechnung von Eisenbahnlärm und Bewertung von Lärmminderungsmassnahmen mithilfe von Prognoseverfahren nach dem neuesten Stand der Technik (Calculation of railway noise and evaluation of noise reduction measures based on prediction methods according to latest state of technology). Lärmbekämpfung 2013, 4:147-152 (in German).

53. Ali SA: Railway noise levels, annoyance and countermeasures in Assiut, Egypt. Appl Acoust 2005, 66:105-113.

doi:10.1186/2052-336X-12-14

Cite this article as: Zannin and Bunn: Noise annoyance through railway traffic - a case study. Journal of Environmental Health Sciences \& Engineering 2014 12:14.

\section{Submit your next manuscript to BioMed Central and take full advantage of:}

- Convenient online submission

- Thorough peer review

- No space constraints or color figure charges

- Immediate publication on acceptance

- Inclusion in PubMed, CAS, Scopus and Google Scholar

- Research which is freely available for redistribution

Submit your manuscript at www.biomedcentral.com/submit 